\title{
L-028 ネガティブ記憶の意図的・非意図的抑制
}

\author{
講演者: 小林 正法 (東京大学) \\ 司会者: 杉浦 義典 (広島大学)
}

ネガティブな出来事を記憶していることは, 将来の類似した状況において素早い反応 (flight or fright) を促すため, 生態学的に重要な意味を持つ。しかしながら, ネガティブ記憶を思い出すことによっ て, ネガティブ気分が誘導され，そのネガティブ気分が気分一致バイアスを通じて，ネガティブ記憶を 想起させるという負の循環（e.g. Teasdale, 1988）も知られている。このような点から, ネガティブな 記憶を抑制することは精神的な健康に繋がると考えられる。本講演では, 意図的抑制, 非意図的抑制そ れぞれを用いたネガティブ単語記憶の抑制の検討について報告を行う。意図的な抑制手法には, Think/no-think課題による意図的抑制，非意図的な抑制手法には，検索誘導性忘却をそれぞれ用いた。 一連の実験結果を報告した上で，ネガティブ単語記憶の抑制が生じる条件について議論する。 